\title{
The Regulation of Fertility in Pre-Industrial Populations: A Local Study from Eighteenth Century Finland
}

\section{BEATRICE MORING}

\author{
Visiting Scholar \\ Cambridge Group for the History of Population \\ and Social Structure \\ Cambridge, England
}

\begin{abstract}
The crude birth rate in Finland in the eighteenth century was more than 40 per thousand. At the same time there was considerable regional diversity. This study of a coastal population in southwestern Finland reveals that the fertility was well below that of the country as a whole and as low or even lower that that recorded for neighboring countries. A more detailed study of families in Houtskär indicates that the pattern of fertility varied according to the socioeconomic standing of the family head. Differences in age at first marriage were a critical determinant of these variations but other important factors were birth spacing and the timing of the last birth. A conscious attempt was made to limit family size.
\end{abstract}

Keywords: fertility, birth spacing, family planning, socioeconomic status, coastal population, Finland

\section{Introduction}

One popular and enduring myth is the idea that families in pre-industrial societies had many children. The childhood memories of the generation born at the end of the nineteenth or in the early decades of the twentieth century helped to launch the stereotype, but it is also reinforced by the illustrations in publications on the history of the family which favor family groups with parents surrounded by numerous children. We need to keep in mind that these were the families of the demographic transition, formed before effective and universal contraception became available but after the mortality decline of the nineteenth century and that even then only a small minority produced as many as ten children.

The traditional view of pre-industrial demography is that its essential characteristics were a high level of fertility and a high level of mortality with a number of crises keeping the balance between resources and population. This classical Malthusian view inspired a debate about the direct and indirect ties between population size, resources, and the role of epidemics. Thomas McKeown, one of the most well-known proponents 
of the Malthusian perspective, has denied the very possibility of the deliberate control of fertility in the pre-industrial era. However a number of other scholars have challenged the theory that populations in the past simply accepted that they were unable to control their own fertility and have found evidence of family planning in past societies. From this research a balanced view has emerged that the level of fertility was the product of both biological imperatives and human manipulation (McKeown and Brown 1965, 296-298, 304-306; McKeown 1985, 35-38; Wrigley and Schofield 418431, 435-438; Wrigley 1969, 165-178, 182-188; Kaukiainen 1987, 27-31; Kaukiainen 1973, 103-104, 116-119; Turpeinen 1976, 209-218; Turpeinen 1979, 106; Anderson 1988, 46-49; Dupaquier and Lachiver 1969, 1391-1406; Gaunt 1973, 47-52; Eriksson and Rogers, 135-141).

In the 1980 s the question of family planning in the Nordic countries was debated by Ulla-Britt Lithell and Christer Winberg. The former held that the level of fertility was determined by a combination of breast-feeding and disease, while the latter maintained that family limitation had been practiced in pre-industrial Sweden and that biological factors could not account for the small size of many families. Winberg went on to claim that breast-feeding was one of a number of contraceptive measures. As evidence he pointed to differences in the spacing of children and the timing of the last birth in different social groups. It might perhaps seem inappropriate to refer to family planning in an eighteenth century context when reliable and widespread forms of contraception only became available after the Second World War. John Knodel, for example, has postulated that when people have used breast-feeding or abstained from sexual intercourse in order to extend the interval between births but not necessarily to stop giving birth altogether, that activity should not be considered as a form of family planning. On this issue I would like to support Winberg's view that it is not necessarily a question of the means adopted or its timing relative to the point in the family's life-cycle but the intention to limit the number of children that should be seen as decisive (Ahlberger and Winberg 1987, 378-381; Winberg 1988, 239-243; Lithell 1988, 233-239; Knodel 1977, 220; Turpeinen 1979, 106). Any attempt to limit the number of children, whatever the means adopted, constitutes a form of family planning.

The crude birth rate in Finland during the eighteenth century was slightly more than 40 per thousand, higher than in any other Nordic country and most of the European countries with surviving data. Studies of nineteenth century Finland indicate 67 children per family in areas with a crude birth-rate around 40 and 5-6 children per family where the rates were lower. However, there were considerable regional differences, with high fertility in the east and much lower fertility in the west, in part clearly connected with the differences in the age at first marriage. The fertility transition also commenced in western and urban areas and only reached the eastern part of the country later (Anderson 1988, 29-33; Kaukiainen 1973, 103-105; Lindgren 1984, 49, 84; Notkola 1989, 56, 209; Moring 1995).

The information presented in this article has been collected as part of a family reconstitution study of one locality, Houtskär parish, in coastal southwestern Finland in the eighteenth and the nineteenth century. The parish registration of births, marriages and deaths, the communion books and the poll-tax registers constitute the principal sources. 547 couples married between 1738 and 1810 have been followed over time, 350 of these falling into the category of completed families (i.e. when the wife was married before the age of 35 and when the marriage remained intact until she had reached the age of 45), permitting the calculation of refined measures of fertility. Only 63 of the 547 families left the parish while the other families were incomplete because of the high age of the woman at marriage or the death of either spouse before the end of the fertile period. A database of these families was constructed and supplemented with information from another database on all the births between 1742 and 1825 . 
In the coastal area the birth rate was 10 percent lower than in the rest of the country (Moring 1989, 150; Moring 1994, 98; Stierncreutz 1957, 73). In line with this the reconstitution results for Houtskär shows that the families were not very large. The 547 marriages contracted between 1738 and 1810 produced just one family of 14 children while it was rare even to find as many as ten children. The average was between 4 and 5 children per family. The mean birth interval and the low mean age of women on the birth of their last child also indicate that some form of family limitation was practiced in this society (Family reconstitution study Houtskär; Moring 1994, 97-108).

\section{Age-specific marital fertility}

Mean birth intervals, the timing of the last birth and age-specific marital fertility have been the criteria most commonly used when trying to determine whether the fertility in a society has been "natural" or if regulation has been attempted. Age-specific marital fertility is a measure of the number of children born to 1000 married women of a given age. If every married woman in the age-group 25-29 gave birth to one child per year, the age specific marital fertility of this cohort would be 1000 . If the average was two children in five years, the rate would be 400 . Age-specific marital fertility has been calculated in this way for different parts of Europe in the eighteenth and nineteenth centuries.

Populations which exhibited a steep decline in the level of fertility through a lengthening of the birth intervals have been assumed to have been practicing contraception. Specific examples are Åsunda and Alskog in Sweden and Meulan in France. Crulai in seventeenth century France, studied by Louis Henry, is now viewed as a classic case of a non-contracepting population. Knodel has used demographic data for a number of German populations and reached the conclusion that in these societies so called "natural" fertility was the rule in the eighteenth century. Nor does Dyrvik's study of U1lensaker in Norway produce any evidence of fertility control (Eriksson and Rogers 1978, 125; Gaunt 1973, 43; Dyrvik 1983, 124; Wrigley 1969, 166; Dupaquier and Lachiver 1969, 1406; Henry 1965, 448; Knodel 1978, 488).

If we compare the results of the family reconstitution study of Houtskär in southwestern Finland with these other populations, it evident that the level of fertility in Houtskär was more in line with the areas where contraception was in use, than with areas of unregulated fertility (Table 1).

T a ble 1. Age-specific marital fertility in European populations 1700-1850.

$\begin{array}{lrrrrrrr} & & 15-19 & 20-24 & 25-29 & 30-34 & 35-39 & 40-44 \\ \text { Åsunda Swe } & 1820 \mathrm{~s} & 360 & 337 & 295 & 234 & 182 & 79 \\ \quad \text { \# " } & 1850 \mathrm{~s} & 350 & 393 & 321 & 236 & 165 & 77 \\ \text { Alskog Swe } & 1700 \mathrm{~s} & 323 & 363 & 344 & 269 & 208 & 99 \\ \text { Ullensaker No } & 1700 \mathrm{~s} & 434 & 439 & 391 & 338 & 277 & 179 \\ \text { Colyton Fr } & 1700 \mathrm{~s} & 500 & 441 & 361 & 347 & 270 & 152 \\ \text { Meulan Fr } & 1700 \mathrm{~s} & 476 & 433 & 331 & 253 & 159 & 53 \\ \text { Crulai Fr } & 1700 \mathrm{~s} & 320 & 419 & 429 & 355 & 292 & 142 \\ \text { Waldeck Ger } & 1700 \mathrm{~s} & - & 441 & 392 & 370 & 281 & 178 \\ \text { Werdum Ger } & 1700 \mathrm{~s} & - & 471 & 406 & 340 & 270 & 120 \\ \text { Houtskär Fi } & 1700 \mathrm{~s} & 389 & 398 & 366 & 291 & 221 & 84\end{array}$

Sources: Eriksson and Rogers 1978, p. 125; Gaunt 1973, p. 43; Dyrvik 1983, p. 124; Wrigley 1969 , p. 166; Dupaquier and Lachiver 1969, p. 1406; Henry 1965, p. 448; Knodel 1978, p. 488; Houtskär family reconstitution study.

Abbreviations: Swe $=$ Sweden, $\mathrm{NO}=$ Norway, $\mathrm{Fr}=$ France $;$ Ger $=$ Germany, $\mathrm{Fi}=$ Finland . 
Even prior to the menopause, increasing age reduces the chances that the woman will conceive. This is not an unimportant matter for those individuals considering their life strategies, such as the timing of marriage. In Houtskär there was considerable variation in age at marriage between landholders and landless. The boatmen, who achieved their maximum earnings as young adults, married early but found themselves older wives. Farmers on the other hand married relatively early, had the youngest wives, and most children (Moring 1994, 78). Their 5-6 children, born during a marriage lasting on average almost twenty years of the fertile period of the wife, however, was far below the fertility level of non-contracepting societies in the past. The level of fertility also fell far short of biological maximal levels calculated for modern non-contracepting populations which are not under-nourished. The mean of 3-4 children in completed landless families was a clear indication that measures were taken to limit the number of children (Tables 2 and 3).

In eighteenth century Europe five children per family was not unusual, fewer in urban and more in rural areas, although Knodel found a large number of children in several non-contracepting German populations (Henry 1965, 441; Deprez 1965, 620; Eversley 1965, 46-48, Knodel 1978, 491; Sheps 1965, 65-80; Huntington and Hostetler 1966, 321-324).

\section{Family limitation}

There has been much discussion of the extent to which populations in the past were able to determine the size of their families. Some scholars have denied the existence of any conscious action, arguing that only nutritional level, disease, and other biological disturbances of reproduction have any power to reduce the level of fertility below its biological maximum. Other scholars accord individuals in the past a more active role. Even today in some societies the issue of contraception remains controversial yet the clergy have been debating the question of both abortion and contraception for a number of centuries and whether they were menial or capital sins. One theory is that the Church began to focus on this question in the Middle Ages when it was faced with the problem of finding enough people to work the extensive lands which had come into its possession. From then on the message remains the same: the marriage bed is there for procreation, not for pleasure (Heinsohn and Steiger 1985, 74-75, 95-96, 106107; Flandrin 1969, 1370-1389; Burguière 1987, 51-52).

The French were the first European society to limit their progeny to such an ex-

$\mathrm{T}$ a b l e 2. Number of children per marriage, by social status of father, in Houtskär 1738-1810.

Farmers

5.7

Farmhands and

inmates 3.5

Crofters

Boat-men

Craftsmen

All non-farmers

All

Sources: Family reconstitution study, couples married in Houtskär 1738-1810, completed families.
$\mathrm{T}$ a b l e 3. Percentage of marriages producing less than 5 children, by social status of family head in Houtskär 1738-1810.

$\begin{array}{ll}\text { Farmers } & 32.9 \\ \text { Farmhands and inmates } & 72.0 \\ \text { Crofters } & 63.6 \\ \text { Boat-men } & 68.0 \\ \text { Craftsmen } & 69.2\end{array}$

Sources: Family reconstitution study, couples married in Houtskär 1738-1810, completed families. 
tent that the fall in fertility can be seen in the statistics of the nation as a whole. Even before the eighteenth century individuals were aware of a number of ways in which they might be able to limit the number of births but by the end of the eighteenth century the practice of contraception had become much more general. However, there is little direct evidence as to the forms of contraception adopted. In the Nordic countries the clergy bemoaned the fact that people committed "serious sins" in their attempts to limit the size of their families. References on these lines appear in early work on population statistics, the inspiration for which was the desire on the part of the state to increase the numerical strength of the country. The needs of the state were clear. A numerous population offered a prospect of more taxes for state business and more soldiers for the state army, objectives not always shared by the population at large (Flandrin 1969, 1370-1389; Hjelt 1899, 84-86).

Already the pre-christian Nordic legal code referred to the fact that long periods of breast-feeding could reduce the risk of conception. Recent research by demographers and biologists has established the importance of nutrition in combination with breast-feeding and partial sterility as determinants of the level of fertility. Harvest failure provoked an increase in the number of miscarriages (Sogner 1984, 40-41; Eversley 1965, 47; Leslie and Fry 1989, 110-112). There are also examples of sterility resulting from difficult deliveries (Dyrvik 1988 125; Knodel 1978, 496).

The interaction between the frequency and duration of breast-feeding and the level of fertility has been the focus of a number of debates (Ahlberger and Winberg 1987, 372-375; Winberg 1988, 239-243; Lithell 1988, 232-239; Ahlberger 1988, 116-121). It has been shown, for example, that the impact of breast-feeding on the level of fertility is limited when long intervals elapse between feeds, as when children are only breast-fed during day-time. By contrast in societies where one, two or three-year-old children are breast-fed at short intervals, a period as long as four years may occur between one birth and another (Konner and Worthman 1980, 788-791; Galdikas and Wood 1990, 189; Notkola 1989, 35-42).

Our knowledge about such issues as they affect historical populations is severely limited. Doctors and clergymen of the time at best based their observations on a handful of individual cases but often only rely on second-hand information. Yet they still voice categorical statements about breast-feeding or the lack of it and make sweeping claims about its duration. Fortunately, the absence of breast-feeding can usually be inferred from an extremely high level and a distinctive seasonal pattern of infant-mortality. On the other hand, the intensity of breast-feeding in any historical population is much more difficult to determine (Brändström 1984,176-184; Lithell 1981, 22-23, 34, 38, 51; Moring 1993).

Before the ready availability of modern contraceptive methods in the mid-twentieth century, coitus interruptus was probably the most widespread form of contraception in combination with prolonged breast-feeding and abstention. Coitus interruptus required no financial outlay, was easy to understand, was always available and if diligently practiced resulted in the birth of fewer children even if it did not altogether preclude further conceptions (Eriksson and Rogers 1978, 135; Frykman 1975, 133; Carlson 1966, 150; Gaunt 1973, 50; Sogner 1984, 41-42). This method might have seemed the best when the desired number of children had been achieved whereas prolonged breast-feeding served only to lengthen birth intervals.

\section{Spacing}

A study of birth intervals raises a number of interesting issues. It is perhaps not surprising that the interval between marriage and the birth of the first child was fairly 
short, regardless of the social status of the parents, and that the interval between the first and the second child was considerably longer. The average interval between marriage and the birth of the first child in the eighteenth and early nineteenth century was 13 months, but in almost 30 percent of the cases the child was born less than 8 months after marriage (in 16 percent of the cases the interval was no more than 2 months). The average interval between the birth of the first and the second child was approximately 30 months and 33-35 months between later births (Table 4).

Although the interval between marriage and the birth of the first child was more or less the same for all social groups, the land-holding families had their second child 28 months after the first, while the landless waited 32 months and the interval between the second and the third child was six months longer for the landless than for the farmers.

Elsewhere in Europe during the eighteenth century, in societies with no contraception an interval of 15-18 months between marriage and the first birth and 23-26 months between the first and the second child was usual. Birth interval of 40 months and more occurred in families practicing family limitation in France at the end of the eighteenth century (Eversley 1965, 47; Knodel 1981, 67-70; Dupaquier and Lachiver $1969,1400)$. On the other hand birth intervals of around 30 months can be considered "normal" once due allowance is made for temporary sterility after delivery, breastfeeding and nine months of pregnancy (Eriksson and Rogers, 1978, 139-140). The decrease in fecundity with increasing age also increases the spacing between births.

A common approach by historical demographers when calculating birth intervals has been to select only those families with at least six children. This manner of sampling introduces certain biases into the results as admitted by those using the method in question (Dupaquier and Lachiver 1969, 1348-1399; Deprez 1965, 618). Accordingly in my study all fertile completed marriages have been included. If the research objective is to record the behavior of an entire population, an exceptional group such as those who have six children or more should not be chosen as characteristic of that society.

Average birth intervals in Houtskär in the eighteenth century were longer than those of non-contracepting European populations in the past. It is possible to see intervals of this order as resulting from physiological reasons in combination with breast-feeding. The practice of breast-feeding can be inferred from the differences in the length of the interval when an infant died before reaching the age of one, and the birth inter-

$\mathrm{T}$ a b l e 4. Birth intervals in fertile marriages in Houtskär 1738-1810.

\begin{tabular}{|c|c|c|c|c|c|}
\hline & Farmers & & Others & & All \\
\hline Interval & Months & Number & Months & Number & Months \\
\hline M-1ch & 13.5 & 287 & 13.7 & 177 & 13.6 \\
\hline $1-2 \mathrm{ch}$ & 28.5 & 267 & 32.9 & 137 & 30.0 \\
\hline $2-3 \mathrm{ch}$ & 31.6 & 234 & 37.8 & 97 & 33.4 \\
\hline $3-4 \mathrm{ch}$ & 32.9 & 192 & 36.6 & 71 & 33.9 \\
\hline $4-5 \mathrm{ch}$ & 35.5 & 160 & 35.8 & 43 & 35.5 \\
\hline $5-6 \mathrm{ch}$ & 36.8 & 117 & 32.8 & 25 & 36.0 \\
\hline $6-7 \mathrm{ch}$ & 33.3 & 77 & 34.0 & 13 & 33.4 \\
\hline $7-8 \mathrm{ch}$ & 32.6 & 45 & 36.8 & 5 & 33.0 \\
\hline $8-9 \mathrm{ch}$ & 33.1 & 27 & 37.0 & 3 & 33.5 \\
\hline $9-10 \mathrm{ch}$ & 23.4 & 14 & 30.0 & 2 & 24.3 \\
\hline $10-11 \mathrm{ch}$ & 31.6 & 7 & - & - & 31.6 \\
\hline $11-12 \mathrm{ch}$ & 24.0 & 2 & - & - & 24.0 \\
\hline
\end{tabular}

Sources: Family reconstitutions study couples married in Houtskär 1738-1810.

$\mathrm{M}=$ marriage, $1 \mathrm{ch}=1$ child, $2 \mathrm{ch}=2$ child etc . 
val when a child survived to at least the age of three. In the former case the interval was 23 months and in the latter 34 months. In addition, there is independent confirmation from the nineteenth century that children were breast-fed in this area (Family reconstitution study Houtskär; FLH VII, 238, 572, 581; FLH VIII, 469-470).

Birth intervals on their own, however, do not suffice to explain the different fertility levels of the various social groups in Houtskär and for further elucidation it is necessary to examine the timing of the last births.

\section{The timing of the last birth}

In order to measure the mean age of the mother at the birth of her last child a particular set of families has been selected for Houtskär conforming to the criteria put forward by Dupaquier and Lachiver in their fertility calculations: marrriages lasting until the wife is more than 40 years old contracted before the wife had reached the age of 35 , "so called completed marriages".

In these families the average age of the wives of farmers when giving birth to their last child was 36,4 while the wives of non-farmers were only 33.8 (Table 5). It has been claimed that in a system of unregulated fertility the last birth should occur on average when the wife was about 40 . When the last birth occurs much earlier in the life of the woman human influence is indicated (Knodel 1978, 503; Dyrvik 1983, 125; Deprez 1965, 616; Henry 1965, 450).

It should therefore be stressed that some women in Houtskär did give birth at the age of 43 and six women even at the age of 45 . Usually, however, the last child arrived when the mother was still fairly young. Studies of localities on the Finnish mainland in the nineteenth century do not show any signs of fertility regulation until the end of the century (Lindgren 1984, 115) but the level of fertility between 1750 and 1900 was indeed lower in the coastal area than in the rest of Finland (Pipping 1964, 23).

The family reconstitution of Houtskär also revealed that with an average of 21 fertile years per marriage for farmers and 18 years for other social groups, 33 percent of the landholding families had fewer than 5 children compared with 68 percent of the others. In the population as a whole 45 percent had fewer than five children and five percent were childless (Table 3).

It has been claimed that illness, especially smallpox, can affect the fertility level of men as well as women and undoubtedly smallpox was present in this coastal society. It is hard to explain the fact though that, if anything, there was a decrease, not an increase, in fertility when it may be presumed smallpox became less prevalent with the introduction into the area of vaccination against smallpox. Nor is smallpox an illness that discriminates between different social groups although their fertility levels

$\mathrm{T}$ a b l e 5 . Average age of mother at the time of the last birth by social status of household head in Houtskär 1738-1810.

$\begin{array}{lc}\text { Status of husband } & \text { Years } \\ \text { Farmers } & 36.4 \\ \text { Farmhands } & 31.3 \\ \text { Inmates } & 32.4 \\ \text { Corofters } & 32.2 \\ \text { Boat-men } & 38.4 \\ \text { Craftsmen } & 35.0\end{array}$

Sources: Family reconstitution study, couples married in Houtskär 1738-1810, completed families. 
differ (Tedebrand 1995; Moring 1994, 98; Population Tables, information on smallpox vaccination). Neither can the level of fertility be explained by age-specific sterility or severe nutritional problems. On the contrary human agency is indicated. Women from all social groups stopped giving birth before the end of their fertile period.

A particular case is that of the wives of the boat-men. These women married later on average than other landless women in this coastal society. The wives of boat-men therefore had their first child at a later age than did the wives of crofters or farm-hands. Yet the average number of children of boat-men $(3,6)$, was more or less the same as for other landless families. The explanation lies with the fact that on average the wives of boat-men were 38,4 when their last child was born whereas other landless women at the time of their last birth were only 32 .

It seems that two parallel strategies existed among the landless. Some groups had their children between the age of 25 and 35, while others had them between 30 and 40 , depending on the social position of the family. However, the total number of children was very low compared with experience of populations on the Finnish mainland. Family limitation though, was not confined to the landless, in this coastal society. In half of Houtskär farming families the last child was born before the farmer's wife reached the age of 36 .

Such differences in fertility and family size depending on social position have also been shown by Kaukiainen to be present in a locality on the southern Finnish mainland during the 1830 s and 1840 s. In this population, too, the wives of farm-hands stopped giving birth earlier than the wives of farmers (Kaukiainen 1979, 17, 28).

Measurement of the evolution of fertility patterns makes clear that there was a decrease in the average number of births per family following the decline in the proportion of marriages involving farmers. Thus there were five children per family in the marriages contracted between 1738 and 1780 and only 4.5 for marriages contracted between 1781 and 1810 . The variation in the age at marriage of the different social groups also affected the level of fertility. The families of farmers formed between 1738 and 1780 produced 5.8 births on average while farmers who were members of the marriage cohorts 1781-1810 had 5.1 children.

From the end of the eighteenth century the non-landowning groups married somewhat earlier which resulted in 3.0 children for those marrying between 1738 and 1780 and 3.8 for those marrying between 1781 and 1810 .

The landholders were faced with the need to limit the size of their families to prevent the social descent of their offspring. The overall numbers in the landless group were affected by the fact that the early nineteenth century brought with it the abolition of the boat-man system, a group with a very high age at marriage. This, however, was more than counterbalanced by a considerable increase in the number of crofts. The reproduction rate of the crofters was somewhat higher than that of the other landless groups and their ever increasing presence in the reproducing population can be seen as responsible for a slight change in the fertility pattern.

\section{Conclusion}

When comparing the fertility level in southwestern Finland with that of the rest of the country, a lower reproduction rate is evident. There is no evidence, however, that these differences could be explained by a higher rate of morbidity or a lower nutritional level. Illness was present everywhere in pre-industrial societies, on the mainland as well as along the coast. If anything, the nutritional situation in a region with multiple sources of income: farming, fishing, animal husbandry, hunting, boat-building etc, was far better than that in areas dependent on farming only. Evidence of this 
can also be found when studying the impact on the total population of years of crises, such as those of the 1690 s or the 1860 s.

Within the locality, variation in the reproductive behavior of different social groups is also evident. Such variation was in part determined by differences in age at marriage: farmers married earlier than the landless. A link between the timing of marriage and socioeconomic position can be readily expected, but spacing between children is another matter. Nevertheless it is clear that the number of children born to the landless was smaller and the interval between the births was longer than for the landholders. From the perspective of today it is easy to reason that a small number of children would be an advantage to those who were dependent solely on their own working ability, while the need to have at least one surviving child who could take over the farm would be a concern for the farming group.

The age at which the landless stopped giving birth was clearly below the level of what could be expected within a system of "natural" fertility. Even the average age at which the women in the landholding group had their last child is sufficiently low to give rise to the suspicion that there was deliberate control of family size. What means were adopted is not clear but the effect of breast-feeding on fertility was known as well as other techniques, judging from the utterances of eighteenth century clergymen.

In retrospect it seems as if landholders as well as the landless were adopting a strategy of reproduction adjusted, as far as possible, to their ability to support and guarantee the future well-being of their offspring.

\section{References}

Ahlberger, Christer. 1988. Vävarfolket-Hemindustrin i Mark 1790-1850. Göteborg.

Ahlberger, Christer and Christer Winberg.1987. Biologi, medvetet handlande och struktur: en studie i amning, spädbarnsdödlighet och fruktsamhet i två västsvenska samhällen. Historisk Tidskrift 3:357-382.

Anderson, Michael. 1988. Population Change in North-Western Europe, 1750-1850: Studies in Economic and Social History. London.

Burguière, André . 1987. The formation of the couple. Journal of Family History 12(1-3):39-53.

Brändström, Anders. 1984. De kärlekslösa mödrarna: spädbarnsdödligheten i Sverige under 1800-talet med särskild hänsyn till Nedertorneå. Umeå.

Carlsson, Gösta. 1966. The Decline in fertility: innovation or adjustment process. Population Studies 20(2):149-174

Deprez, P. 1965. The demographic development of Flanders in the eighteenth century. In: Glass, D.V. and D.E.C. Eversley, pp. 608-630.

Dupaquier, J. and M. Lachiver. 1969. Sur les debuts de la contraception en France ou les deux malthusianismes. Annales Économies, Sociétés, Civilisations 24(6):1391-406.

Dyrvik, Ståle.1983. Historisk demografi. Bergen.

Eriksson Ingrid and John Rogers. 1978. Rural Labor and Population Change. Studia Historica Upsaliensia 100. Uppsala: University of Uppsala.

Eversley D.E.C. 1965. Population, economy and society. In:Glass, D.V. and D.E.C. Eversley, pp. 2369.

Flandrin, J-L. 1969. Contraception, mariage et relations amoureuses dans l'Occident crétien. Annales E.S.C. novembre-décembre.

Frykman, Jonas. 1975. Sexual intercourse and social norms: a study of illegitimate births in Sweden 1831-1933. Ethnologia Scandinavica: A Journal of Nordic Ethnology 111-150.

Galdikas, Birute M.F. and James W. Wood 1990. Birth spacing patterns in humans and apes. American Journal of Physical Anthropology 83:185-191.

Gaunt, David. 1973. Family Planning in the Preindustrial Society: Some Swedish Evidence. Aristocrats, Farmers, Proletarians. Studia Historica Upsaliensia 47. Uppsala.

Gille, Halvor. 1984. World population development in the light of the World Fertility Survey and the latest researches. In: Family and Population: Issues of Fertility in Theory and Practice, edited by Hellevi Hatunen, pp. 19-57. Publication of Väestöliitto no.11. Helsinki: Väestöliitto.

Glass, D.V. and D.E.C. Eversley (ed.). 1965. Population in History. London. 
Heinsohn, Gunnar and Otto Steiger (1985) Häxor: om häxförföljelse, sexualitet och människoproduktion. Göteborg.

Henry, Louis. 1965. The Population in France in the Eighteenth Century. In: D.V. Glass and D.E.C. Eversley, pp. 434-456.

Hjelt, August. 1899. De första officiella relationerna on Svenska Tabellverket åren 1749-1757. Helsingfors.

Imhof, Arthur. 1984. The amazing simultaneousness of the big differences and the boom in the 19th century - some facts and hypotheses about infant and maternal mortality in Germany, 18th to 20th century. In: Pre-Industrial Population Change, edited by Tommy Bengtsson, Gunnar Fridlizius, and Rolf Ohlsson, pp. 191-222. Stockholm: Almquist and Wiksell International.

Kaukiainen, Yrjö. 1973. Miksi kansa lisääntyi? Ajatuksia syntyvyyden ja kuolevuuden vaikutuksesta ja vuorovaikutuksesta. Historiallinen Aikakauskirja (2):103-121.

Kaukiainen, Yrjö. 1979. Social Structure and Demographic Development in a Southern Finnish Parish (Lohja) 1810-50. Annales Academiae Scientiarum Fennicae, ser.B, tom.204. Helsinki: Suomalainen Tiedeakatemia.

Kaukiainen, Yrjö. 1987. Population growth and land availability in south-east Finland 1750-1840. In: Evolution agraire et croissance demographique, edited by Fauve-Chamoux Antoinette, pp. 263 289. Liège.

Knodel, John. 1977. Family limitation and the fertility transition: evidence from the age patterns of fertility in Europe and Asia. Population Studies 31(2):219-249.

Knodel, John. 1978. Natural fertility in pre-industrial Germany. Population Studies 32(3):481-510.

Knodel, John and C. Wilson. 1981. The secular increase in fecundity in German village populations: an analysis of reproductive histories of couples married 1750-1899. Population Studies 35(1):5384 .

Konner, Melvin and Carol Worthman.1980. Nursing frequency, gonadal function and birth spacing among! Kung hunter-gatherers. Science 207(4432): 788-91.

Lindgren, Jarl. 1984. Towards Smaller Families in the Changing Society. Publications of the Population Research Institute Serie D, no.11. Helsinki: The Population Research Institute.

Lithell, Ulla-Britt. 1981. Breast-Feeding and Reproduction: Studies in Marital Fertility and Infant Mortality in 19th century Finland and Sweden. Studia Historica Upsaliensia 120. Uppsala: University of Uppsala.

Lithell, Ulla-Britt. 1988. Amning och äktenskaplig fruktsamhet. Historisk Tidskrift (Stockholm) 2:232238.

McKeown, Thomas and R.G. Brown. 1965. Medical evidence related to English population changes in the eighteenth century. In: Glass, D.V. and D.E.C. Eversley, pp. 285-307.

McKeown Thomas. 1984. Food, infection and population. In: Hunger and History: The Impact of Changing Food Production and Consumption Patterns on Society, edited by Robert I. Rotberg and Theodore K. Rabb. Studies in Interdisciplinary History. Cambridge, England: Cambridge University Press.

Moring, Beatrice. 1993. Allmogens barnsyn i det agrara Finland och överhetens vantolkningar av densamma. Historisk Tidskrift för Finland 78(1):16-33.

Moring, Beatrice. 1993. Sjömans och båtsmansfamiljernas livsvillkor i sydvästra Finlands skärgård under 1700- och 1800-talen. Bottnisk kontakt VI 1992. Gävle

Moring, Beatrice. 1994. Skärgårdsbor: hushåll, familj och demografi i finländsk kustbygd på 1600-, 1700- och 1800-talen. Bidrag till kännedom av Finlands natur och folk 145. Societas Scientiarum Fennica. Helsingfors: Finska Vetenskaps-Societeten. Doctoral Dissertation.

Notkola, Irma-Leena. 1989. Luonnollisesta hedelmällisyydestä lapsirajoitukseen: mikrodemografinen tutkimus hedelmällisyyden transitiosta. SuomenVäestötieteen Yhdistyksen Julkaisuja 12. Helsinki: Suomen Väestötieteen Yhdistys. Doctoral Dissertation.

Pipping, Knut. 1964. Lounaisen saaristomme väestönkehitys. Väestöntutkimuksen vuosikirja 8:22_ 35.

Sheps, M.C. 1965. An analysis of reproductive patterns in an American isolate. Population Studies 19(1):65-80.

Sogner, Sölvi. 1984. Fra stua full till tobarnskull. Oslo.

Stierncreutz, Patrik. 1957. Befolkningsutvecklingen i sex kommuner i sydvästra Finlands skärgård. Opublicerad pro gradu avhandling Åbo: Åbo Akademi, Samhällsvetenskapliga institutionen.

Tedebrand, Lars-Göran 1995. Skärgårdshushåll: granskningar. Historisk Tidskrift för Finland 80(4): 461-464.

Turpeinen, Oiva. 1976. Fertilitetens årliga fluktuationer och familjeplanering i Finland under den förindustriella tiden. Historisk Tidskrift för Finland 61(3):209-218.

Turpeinen, Oiva. 1979. Infant mortality in Finland 1749-1865. Scandinavian Economic History Review 27(1):1-21. 
Turpeinen, Oiva. 1979a. Monthly mortality in Finland 1751-1806. Yearbook of Population Research in Finland 17:58-73.

Wrigley, E.A. 1969. Family limitation in pre-industrial England. In: Population in Industrialization, edited by William D. Drake, pp. 157-194. London.

Wrigley, E. Anthony and Roger Schofield. 1981. The Population History of England, 1541-1871: A Reconstruction. London. 